\title{
CONTROLE ADMINISTRATIVO E "OMBUDSMAN"
}

\author{
Eduardo Lobo Botelho Gualazzi* \\ Professor Associado da Faculdade de Direito da Universidade de São Paulo
}

\begin{abstract}
Resumo:
Utilização do Direito Comparado. Espécies de controle e seus limites. Ombudsman sueco: origem histórica da instituição. Ombudsman em outros Estados. Brasil: Comissão de Defesa dos Direitos do Cidadão (CÓDICI). Tribunais de Contas no Brasil: competências constitucionais assemelhadas às de um Ombudsman.
\end{abstract}

\begin{abstract}
:
Use of Comparative Law. Types of control and their limits. The Swedish Ombudsman: the historical origin of the institution. The Ombudsman in other states. Brazil: Commitee for the Defense of the Rights of the Citizen (CODICI). The Tribunais de Contas in Brazil: the constitutional competences similar to that of the Ombudsman.
\end{abstract}

Entre os temas mais atuais e solicitados, nos Cursos de Graduação, Pós-Graduação e Especialização de Direito Administrativo, encontra-se o de Ombudsman e controle administrativo. No Brasil, aumentam gradativamente a preocupação e o interesse em relação ao controle da Administração Pública, por todos os modos e institutos jurídicos, cabíveis, entre os quais o Ombudsman. Embora ainda inexistente no Brasil, o instituto jurídico-administrativo do Ombudsman já suscitou a publicação de alguns estudos especializados e foi-lhe proposta a criação, na Assembléia Nacional Constituinte, de 1987-88. Não seria surpresa se o Ombudsman fosse afinal criado, no Brasil, durante a futura revisão constitucional, prevista para 1993.

A análise do Ombudsman suscita utilização do Direito Comparado, especialmente do Direito Administrativo Comparado. O Direito Comparado, como se sabe, não é ramo da árvore do Direito. Não é disciplina jurídica autônoma. Não é Direito. É método científico que, recorrendo à observação e ao cotejo, ressalta os traços dominantes de vários sistemas jurídicos, confrontando, no mesmo plano, institutos paralelos e sistemas, para depois concluir pela

\footnotetext{
* Procurador do Estado de São Paulo
} 
universalidade de um conceito ou pela tipificação de um instituto num dado sistema de direito (cf. José Cretella Júnior, Direito Administrativo Comparado, São Paulo, EDUSP, 1972, p. 24).

O conteúdo atual do Direito Comparado configurou-se após longa evolução dos estudos jurídico-científicos. Em séculos passados, a Ciência do Direito dedicou-se a descobrir os princípios de justiça e eqüidade, conformes à vontade de Deus, à natureza e à razão; a premissa de análise, portanto, era predominantemente apriorística, idealista e universalista. Entretanto, esfacelouse paulatinamente a noção de jus commune, de Direito com aplicação universal. Predominou, no século XIX, a noção de nacionalismo, de Direito nacional, estratificado em Constituições e grandes codificações, alicerçadas no apogeu da soberania estatal.

O desenvolvimento, na segunda metade do século XIX, do Direito Comparado, como tal, foi o resultado logicamente inevitável desta nacionalização da idéia do Direito, que teve ascendência na primeira metade do século XIX. Ademais, tornou-se necessário e urgente, em vista da expansão sem precedentes, nos tempos modernos, das relações internacionais e dos contratos de todos os tipos (cf. René David e John E. C. Brierley, Major Legal Systems in the World Today, $2^{\mathrm{a}}$ ed., London, Stevens \& Sons, 1978, p. 3).

'A utilidade atual do Direito Comparado pode ser analisada sob três ângulos: é útil em pesquisa jurídica, histórica e filosófica; é importante para compreender-se melhor e aperfeiçoar-se o Direito nacional; auxilia na promoção do entendimento de povos estrangeiros $e$, assim, contribui para a criação de um contexto favorável ao desenvolvimento de relações internacionais" (Ibidem, p. 4).

Segundo Haroldo Valladão, o Direito Comparado caracteriza-se por cinco ciclos: a) mero exame da legislação estrangeira (princípio a meados do século XIX); b) estudo da legislação comparada (segunda metade do século XIX); c) ciência do Direito Comparado (a partir de 1900); d) internacionalização do Direito Comparado (época contemporânea); e) universalização do Direito 
Comparado (futuro próximo) (cf. Enciclopédia Saraiva do Direito, São Paulo, Saraiva, 1979, v. 25, sub voce Direito Comparado).

Assim, para considerar-se o tema do Ombudsman, é mister realizar-se análise e síntese em termos de internacionalização do Direito Comparado a fim de se verificar a possível inserção e correlata utilidade do Ombudsman no Direito Brasileiro, de lege ferenda.

Ao analisar-se o Ombudsman, sob qualquer ângulo, imediatamente adquire relevância o aspecto das lacunas eventuais no controle da Administração Pública. Aliás, sob enfoque histórico, surgiu o Ombudsman sueco precisamente para remediar lacunas do controle administrativo e, nos dias atuais, nos Estados que adotam o instituto jurídico-administrativo do Ombudsman, sobreleva sua máxima função, consistente em prevenir e preencher lacunas e omissões de outros tipos de controle administrativo e/ou judiciário, atinente aos três Poderes, sobretudo ao Poder Executivo (Administração Pública).

Para assegurar-se a eficácia da Administração e corrigir-lhe os erros há diversos tipos de controle. O controle tende a assegurar a coerência da atividade administrativa: é um fator essencial de coordenação, para o bom funcionamento interno da Administração. $O$ controle assegura ainda que a Administração respeite as regras assentadas pelo poder político e não se imiscua nos direitos e liberdades públicas dos cidadãos. Portanto, o tema conecta-se ao das relações jurídicas entre governantes e governados. $\mathrm{O}$ controle assegura, enfim, de modo mediato, a unidade do Estado, a filosofia política do Estado, condição da existência do próprio Estado.

Os vários tipos de controle concentram-se sempre em facetas específicas: a) o controle administrativo verifica a coerência interna da Administração; b) o controle jurisdicional examinará a observância dos direitos do cidadão; c) o controle político tenderá sobretudo a salvaguardar o respeito às prioridades impostas pela filosofia política inerente à ordem constitucional. Porém, estas espécies de controle apresentam entre si separação excessivamente rígida e insuficiências.

O controle parlamentar da Administração sempre deixa de penetrar em várias zonas cinzentas, não previstas pelos textos legais, bem como não penetra em situações concretas de omissividade ou negligência dos agentes páblicos. O controle jurisdicional é também insuficiente, por sua natureza casual 
e individualizada, porquanto depende de provocação de parte interessada. $O$ controle administrativo interno, por sua vez, exatamente por remanescer ao alvedrio de autoridades públicas da Administração ativa, é freqüentemente menosprezado, quando não solapado.

Enfim, a heterogeneidade das diversas espécies de controle impõe limites objetivos a cada qual, bem como a necessidade de serem todos mantidos em exercício concomitante.

Em conseqüência, houve o surgimento paulatino de órgãos administrativos polivalentes, ecléticos, que buscam associar as vantagens das diversas espécies de controle. Verbi gratia, é o caso do Conselho de Estado francês e, mais especialmente, do Ombudsman sueco, como solução definitiva para o desiderato de controle integral em correlação às relações entre Administração Pública e Parlamento.

Ademais, assinala-se profunda alteração nas relações entre o Estado e o cidadão, entre a Administração Pública e os administrados, ao longo do século $\mathrm{XX}$, sobretudo no tocante ao reforço da autoridade pública e dos poderes administrativos, ao abandono progressivo dos valores liberais do século XIX e à substituição do Estado-gendarme pelo Estado-providência.

Maurice Hauriou já assinalava que "o poder preponderante da Administração implicava em substanciais alteraçōes constitucionais e numerosas restriçōes para as liberdades privadas".

Letourneur realçou que "o conteúdo da legalidade depende da importância do campo livre que se deseja reservar à autoridade, mais exatamente do 'ponto de equilíbrio' que se deseje estabelecer entre os direitos da administração e os direitos dos cidadãos" ( $A$ extensão do controle do juiz no exercício do poder, 1962, p. 51).

No Estado contemporâneo, todavia, a fixação desse "ponto de equilíbrio" e seu controle ulterior não pode ser relegado ao critério da própria Administração Pública.

Por outro lado, como observou Groshens, "a administraçāo da justiça se reduz com demasiada freqüência à administração de tranqüilizantes" (Réflexions sur la dualité de juridiction, 1963, p. 539).

Charles Debbasch considera o exemplo do Ombudsman uma "fonte de inspiração para todos aqueles que, ao desejarem maior eficácia do aparelho 
administrativo, näo se resignam a ver desenvolver-se o poder discricionário da Administraçāo".

Segundo André Legrand, "em nenhum país o Ombudsman exerce controle sistemático e aprofundado de oportunidade. O erro comum que se comete a respeito deste aspecto provém de uma causa simples: por sua existência, o Ombudsman permite o exercício do controle nas áreas em que não existe recurso algum".

Quais os métodos de controle da Administração por meio do instituto jurídico-administrativo do Ombudsman?

A Administração Pública age por meio de atos administrativos, manifestação de vontade destinada a produzir, por meio de decisão autoexecutória, alterações na ordem jurídica. A subordinação dos atos administrativos ao princípio da legalidade é inafastável. Conforme indica Herlitz, "sublinhemos o fato de que as leis indicam expressamente - embora às vezes em termos excessivamente genéricos a natureza dos atos administrativos autorizados, assim como ordinariamente designam as autoridades competentes" (Le Droit Administratif Suédois, p. 542).

Por conseguinte, a competência administrativa da Administração explica-se por um princípio geral - o poder discricionário. Porém, a aplicação deste princípio geral colide com múltiplas exceções, consistentes na afirmação por órgãos superiores da subordinação legal do ato administrativo discricionário.

Segundo Di Qual, "o poder discricionário da Administração é analisado como um poder residual, resultante da afirmação daquele princípio na ausência de exceçōes" (La Compétence Liée, Lille, 1963, p. 435).

Entrementes, adverte Michoud que "o poder discricionário é o poder de uma autoridade que age livren ente sem que sua conduta seja ditada por uma regra de direito" (Étude sur le pouv -ir discrétionnaire, 1913, p. 10).

Porém, o jurista sueco Hammarskjöld, em 1915, negou que o poder discricionário comporte escolha da Administração entre várias soluções possíveis: "para qualquer decisão administrativa, devem existir motivos objetivos $e$ universais, mesmo que seja impossivel precisá-los em detalhes. Por conseqüência, na prática, um só modo de ação pode ser correto e um exame jurisdicional do modo de açāo não constitui em si nada de irrazoável" (Relatório sobre criação de um Tribunal Administrativo, p. 185). 
Segundo André Legrand, "resulta que a existência do poder discricionário não se coliga apenas ao grau de controle judicial. Haverá sobretudo poder discricionário quando o juiz recusa-se a exercer um controle. Ou seja, o poder discricionário deve ser apreciado não-somente em caso de admissāo do recurso, mas também em função das condições de admissibilidade".

Em outros termos, há situações jurídico-administrativas em que não é cabível o exercício legal de qualquer espécie de controle, seja parlamentar, judicial ou administrativo, precisamente porque há casos concretos, de natureza administrativa discricionária, que refogem a qualquer dos tipos tradicionais de controle, interno ou externo: para tais casos concretos, o contrasteamento jurídico-administrativo somente pode ser realizado eficazmente por intermédio do Ombudsman. Eis aí o motivo histórico da criação de tal instituto e a razão de se haver espraiado para muitos Estados contemporâneos. Apenas por tal motivo, deveria o Ombudsman ser implantado no Brasil, aspecto que será melhor analisado em outra passagem deste estudo.

Em suma, o Ombudsman é o único instituto jurídico-administrativo que possibilita aos administrados realizar controle administrativo em relação às lacunas omissivas ou comissivas, às zonas cinzentas e a certos abusos e distorções do poder discricionário no âmbito interno da Administração Pública. $O$ Ombudsman supre e supera a rigidez, a limitação e as deficiências eventuais das outras espécies de controle.

Cumpre considerar-se, agora, o Ombudsman da Suécia, Estado de origem histórica do instituto.

Na história da Suécia, antes da criação do atual Ombudsman, sucedida em 1809, registram-se antecedentes remotos e próximos, atinentes a esse instituto jurídico-administrativo, a saber: a) século XVI Grande Senescal (Drotsen); b) Inspetor Geral (1665/1668); c) Ombudsmannen (1713); d) Justitienkansler (Chanceler de Justiça) (1719); e) Ombudsman do Rei (1720).

Entre os modelos estrangeiros, que poderiam ser considerados como historicamente assemelhados ao Ombudsman sueco de 1809, figurariam os seguintes: a) Justiciat de Aragão (juiz vitalício, nomeado pelo Rei para proteger os particulares em relação aos abusos dos funcionários); b) Tribuno da Plebe romano (controle de todas as Magistraturas); c) Bill of Rigths, de 1689; d) Procurador-Síndico de França (representante dos direitos dos cidadãos, 
sobretudo em matéria fiscal); e) agentes nacionais do Comitê de Salvação Pública, após 1789.

Na Suécia de 1809, havia uma luta entre o Rei e o Parlamento (Riksdag), dominado pela nobreza. A revolução sueca de 1809 encerrou o ciclo de atritos entre o absolutismo monárquico e o parlamentarismo, aspecto que suscitou ao jurista Jellinek considerar, em 1900, que o regime político sueco havia conservado um aspecto medieval.

A Regeringsform sueca de 1809 apenas regula minuciosamente a estrutura e o funcionamento do Poder Executivo, equilibrando os poderes do Parlamento e do Rei: foi influenciada por Montesquieu.

Houve várias inovações na Regeringsform de 1809, muitas das quais foram criações suecas, não copiadas de outros Estados. Entre tais inovações, constou o artigo 96, que criou o Ombudsman, como mandatário do Parlamento, "encarregado de controlar a observância das leis pelos tribunais e funcionários e de acionar perante os tribunais competentes, de acordo com as leis, aqueles que, no exercício de suas funçōes, houverem por parcialidade, favor ou qualquer outro motivo, cometido ilegalidades ou negligenciado a execução conveniente dos deveres de seu oficio".

Na Suécia, o Ombudsman surgiu, em 1809, como reação de uma Assembléia que intentava reservar-se largos poderes de vigilância sobre a justiça e a administração. O Parlamento sueco (Riksdag) almejava, por meio do Ombudsman, equilibrar seus poderes com os do Rei, que dispunha do Chanceler de Justiça (Justitienkansler). Na Suécia de 1809, buscou-se o "dualismo" político, equilibrio entre Poderes Executivo (Rei) e Legislativo. Uma das soluções para esse "dualismo" foi o Ombudsman. No princípio (1809), o Ombudsman sueco tinha apenas competência para acusar funcionários faltosos perante Tribunais, precisamente porque o Ombudsman situava-se fora da hierarquia administrativa. Somente após longa evolução histórica o Ombudsman tornou-se um órgão semiautônomo de controle administrativo.

O Ombudsman sueco é eleito pelo Parlamento para mandato de quatro anos: esta eleição garante sua independência em face do Rei. Os eleitores do Ombudsman sueco, contudo, são escolhidos de acordo com as disposições atinentes à eleição para as Comissões Técnicas do Riksdag: assim, a eleição 
quatrienal do Ombudsman não se politiza. O Ombudsman pode ser eleito até 15 dias após a escolha da Comissão Constitucional, encarregada de escolhê-lo.

O Ombudsman sueco exerce, atualmente, o controle a posteriori da Administração Pública. Não pode o Ombudsman exercer o controle sobre os Ministros, exceto mediante determinação expressa do próprio Parlamento. Há, portanto, expressa divisão entre os atos de governo e os atos de administração. Ao Ombudsman incumbe, primordialmente, controlar e contrastear os atos administrativos dos funcionários. Ao Ombudsman sueco caberá, diante de uma infração penal, representar à justiça ordinária para que o funcionário seja punido. Todavia, estão assegurados privilégios de jurisdição a funcionários de chefia e juízes que poderão ser processados apenas diante da Corte Suprema ou da Corte de Apelo, bem como a bispos, secretários de diocese, padres e professores universitários. A partir de 1967, o Ombudsman sueco passou a exercer controle também sobre as administrações comunais.

O Ombudsman sueco é um delegado do Parlamento para a fiscalização dos atos da Administração, mas não está subordinado ao Parlamento: pode agir de ofício ou por provocação de particular.

$\mathrm{O}$ artigo 96 da Regeringsform exige apenas que a escolha do Ombudsman sueco recaia sobre "um jurisconsulto de notório saber e de integridade particular". Não pode exercer outro cargo público durante seu mandato. O Ombudsman dispõe de absoluta autonomia para a formação de sua equipe de funcionários. $\mathrm{O}$ mandato do Ombudsman sueco somente pode ser interrompido por dois modos: a) o Ombudsman demite-se; b) o Riksdag revoga seu mandato.

O Ombudsman sueco deve apresentar um relatório anual ao Parlamento a respeito de falhas e estado da administração e da justiça.

O Ombudsman sueco adquiriu extrema relevância porque no Parlamentarismo sueco não pode haver destituição do Governo por moção de desconfiança e, nos longos recessos do Parlamento, a Administração Pública é governada pela Comissão Constitucional e controlada pelo Ombudsman.

Em 1915, na Suécia, foi criado o Ombudsman Militar (Militiemombudsman), encarregado de verificar erros que parecessem "poder acarretar que os estabelecimentos da Defesa nacional se desviassem de seu objetivo" 
Além do Ombudsman para a Administração Pública e do Ombudsman Militar, existem na Suécia mais três Ombudsman: a) dos Consumidores; b) para a Liberdade Econômica; c) da Imprensa. O Ombudsman dos Consumidores visa coibir a prática da publicidade enganosa e estabelecer controle de qualidade dos produtos, podendo suscitar questões perante o Tribunal de Mercados. O Ombudsman para a Liberdade Econômica tem como função proteger os cidadãos dos chamados trustes e cartéis econômicos que impeçam a concorrência e o livre mercado, também dispondo da faculdade de suscitar questões perante o Tribunal de Mercados. O Ombudsman da Imprensa tem como função coibir publicação caluniosa ou infração à ética jornalística.

O Ombudsman sueco para a Administração Pública poderá apreciar qualquer matéria, exceto aquelas consideradas pela Comissão Constitucional como de segurança nacional em matéria militar. Para tanto, o Ombudsman dispõe de livre acesso a todos os documentos e arquivos do Estado.

O Ombudsman sueco pode: a) acusar judicialmente o funcionário investigado; b) fazer-lhe recomendação direta; c) fazer-lhe recomendações ou sugestões para a realização de um melhor serviço, sem nenhum caráter sancionador; d) sugerir mudanças de normas ao governo, a fim de adequá-las a eventuais direitos reconhecidos pelo Ombudsman.

No momento atual, na Suécia, encontra-se em vigor o Texto da Instrução do Ombudsman, de 1967. Entre seus vinte e três parágrafos, realçamse os seguintes:

a) $\$ 19$ - Os Ombudsman do Riksdag (Justitiemombudsman) exercem controle a fim de que os funcionários $e$ outras pessoas, submetidas à integral responsabilidade de suas funçōes, observem no exercício de suas funçōes as leis e outros dispositivos e cumpram suas obrigações. Os Ombudsman devem, além disso, agir para suprir as lacunas da legislação e favorecer uma aplicação unitária e oportuna do Direito";

b) "\$ $2^{Q}$ O controle dos Ombudsman exercese por meio de inspeções, bem como pelos quesitos $e$ decisões que podem ser considerados como exigiveis em 
razão das reclamações, das observações efetuadas no curso das inspeções e de outras circunstâncias";

c) "§ $3^{o}$ - Incumbe ao Ombudsman velar pela observância das disposições atinentes às questões de privação administrativa de liberdade, liberdade de imprensa e publicidade dos documentos oficiais, bem como, no tocante ao Ombudsman que exerce o controle sobre a Administração da Defesa, a remuneração e a gestão do pessoal militar";

d) "Os Ombudsman devem principalmente intervir em caso de atentado ou colocação em perigo da segurança jurídica de um particular ou quando qualquer pessoa houver negligenciado suas obrigaçōes de serviço para a busca de um interesse pessoal, por parcialidade ou por grosseira negligência";

e) "\$10 - Os Ombudsman podem assistir às deliberações $e$ decisões dos tribunais $e$ outras autoridades, sem dispor, entretanto, do direito de exprimir sua opinião; eles devem ter acesso aos processos-verbais e documentos das autoridades".

No tocante ao Ombudsman sueco, seus principais meios de atuação são os seguintes: a) recurso de pleno contencioso; b) controle de legalidade da atividade administrativa.

Em relação ao recurso de pleno contencioso, averba-se que o Ombudsman não é um tribunal, nem uma autoridade administrativa. Entretanto, mesmo sem ser um juiz, o Ombudsman pode exercer uma atividade de controle que se aproxima da de um juiz. Segundo Rudolfo Kjellen, há duas hipóteses de recurso de pleno contencioso: a) uma falta subjetivamente grave, atinente à conduta do funcionário faltoso; b) uma falta objetivamente grave, em que o caráter da gravidade resulte da violação de direito. Em qualquer das hipóteses, aliás, trata-se de violação de direito.

No tocante ao controle da legalidade da atividade administrativa, o controle do Ombudsman sueco apresenta características de controle 
administrativo de ofício: a) ausência de interesse; b) latitude em relação às condições temporais; c) existência de poderes de ação de ofício. O Ombudsman exerce controle da legalidade da atividade administrativa nos seguintes casos, verbi gratia: a) poder disciplinar; b) violação das prescrições de serviço; c) ordem ilegal; d) manutenção da ordem interna; e) legalidade interna; f) controle dos motivos; g) controle sobre o objeto dos atos; h) controle das medidas de polícia.

Examinou-se, em síntese, o Ombudsman sueco, criado em 1809. É mister analisar-se, doravante, a irradiação do instituto jurídico-administrativo do Ombudsman sueco para outros Estados.

Consideremos, a seguir, o Ombudsman finlandês, o segundo a ser criado, mais de cem anos após o sueco.

Na Finlândia, coexistem o Ombudsman da Justiça e o Chanceler de Justiça. O Ombudsman deve apresentar relatório anual ao Parlamento. $\mathrm{Na}$ Finlândia, há um parlamentarismo em que os Ministros são responsáveis perante o Parlamento. O Parlamento controla os Ministros com a contínua participação do Ombudsman. O Ombudsman finlandês exerce controle sobre as atas das reuniões ministeriais, a posteriori, por iniciativa própria. Porém, o Chanceler de Justiça finlandês pode exercer controle sobre o próprio Presidente da República. Além de apresentar acusações e admoestações, tanto o Ombudsman como o Chanceler de Justiça podem, na Finlândia, pedir à Corte Suprema ou à Suprema Corte Administrativa que anulem decisões administrativas, tomadas por autoridades recalcitrantes em seguir suas orientações. O Ombudsman finlandês controla toda a Administração Pública (funcionários centrais, locais e Igreja Luterana), bem como Juízes, prestando contas ao Parlamento. O Ombudsman finlandês exerce sua função de modo autônomo, em relação ao Parlamento. Seu mandato é de três anos, podendo ser revogado a qualquer momento, pelo Parlamento. De acordo com a reforma de 1933, o Ombudsman finlandês caracterizou-se como defensor dos direitos do indivíduo finlandês e o Chanceler de Justiça como conselheiro jurídico do Governo. O próprio Ombudsman finlandês controla a Administração militar.

Analisemos, agora, o Ombudsman dinamarquês, implantado em 1946. Aliás, o instituto jurídico-administrativo do Ombudsman irradiou-se para muitos países a partir da adoção do Ombudsman pela Dinamarca, em 1946, ano em que a Constituição dinamarquesa, no artigo 55, passou a ter a seguinte 
redação: "a legislação estabelecerá a nomeação pelo Folketing de uma ou duas pessoas, as quais não poderão ser membros do Folketing, para que fiscalizem a administração civil e militar do Estado" Em 1954, foi finalmente promulgada a lei dinamarquesa do Ombudsman. A Dinamarca tem uma Administração rigidamente hierarquizada e, assim, o controle do Ombudsman abrange também os Ministros. Não se admite controle do Ombudsman sobre os Juízes, em vista da independência da Magistratura em relação ao Governo. O Ombudsman é eleito pelo Folketing, podendo ser destituído a qualquer momento se deixar de merecer a confiança: porém, atua de modo autônomo, em relação ao Parlamento. O Direito dinamarquês garante a total independência do Ombudsman em relação ao Parlamento e ao Governo, mas o Ombudsman remanesce obrigado a apresentar um relatório anual. O controle do Ombudsman não atinge o próprio Parlamento ou os Deputados, exceto quando desempenham funções executivas. Enquanto na Suécia o instrumento de ação do Ombudsman consiste na recomendação a funcionário (estabelecendo-se o contencioso), na Dinamarca o Ombudsman atua por meio de recurso administrativo, não contencioso. Assim, de acordo com a legislação dinamarquesa de 1962, o Ombudsman na Dinamarca dispõe das seguintes faculdades: a) se entender que um Ministro ou ex-Ministro incorreu em responsabilidade civil ou penal, pode apresentar recomendação ao Folketing para que seja processado; b) se entender que qualquer outra pessoa sob seu controle deve responder por falta criminal, pode ordenar investigação preliminar ou acusação perante os tribunais; c) se considerar haver razões para início de procedimentos disciplinares, pode ordenar às autoridades competentes o início; d) pode externar suas opiniões à pessoa a quem se destinar a queixa apresentada.

A seguir, examinemos o Ombudsman norueguês. Na Noruega, existem dois Ombudsman: o civil e o militar. Ao Ombudsman militar incumbe: a) manter-se em permanente e estrito contato com as comissões de representantes; b) conhecer as queixas dos recrutas ou de oficiais; c) conhecer assuntos militares por iniciativa própria; d) atuar como órgão assessor das principais autoridades militares e civis da Noruega. Em 1962, foi criado o Ombudsman civil: eleito para mandato de quatro anos, o Ombudsman exerce de maneira independente sua atividade fiscalizadora; somente maioria qualificada de dois terços pode destituir o Ombudsman durante seu mandato. $\mathrm{O}$ 
Ombudsman norueguês tem competência para apreciar qualquer matéria que envolva a administração civil, inclusive eventuais atividades empresariais do Estado. O Rei, seu Conselho e os Ministros estão excluídos do controle do Ombudsman, pois a este não cabe o controle político, mas apenas o administrativo. Além disso, o Ombudsman está impedido de rever qualquer assunto que já tenha sido apreciado pelo Storting em qualquer de suas duas Câmaras ou na Comissão de Protocolo. O Ombudsman norueguês não pode exercer controle sobre Juízes. Em 1973, na Noruega, foi criado o Ombudsman para o Consumidor, para controle das normas de marketing e a proteção do consumidor em suas relações de mercado, publicidade, propaganda, etc.

A Nova Zelândia foi o primeiro país da Commonwealth a implantar um Ombudsman, em 1962. O Ombudsman neozelandês é designado pelo Governador Geral mediante recomendação da Câmara de Representantes. O mandato do Ombudsman é de três anos. O Ombudsman neozelandês não dispõe de competência direta para fiscalizar atos dos Ministros de Estado. A função do Ombudsman neozelandês limita-se a de recomendar ao Departamento providências administrativas. Se não houver alteração, o Ombudsman pode cientificar o Parlamento a respeito da não observância de seu informe. $O$ Ombudsman neozelandês não poderá controlar atos dos tribunais e de seus funcionários. O Ombudsman neozelandês também não pode investigar os atos das Forças Armadas, da Administração local e da Igreja. De acordo com a lei, o Ombudsman neozelandês pode atuar em relação a qualquer decisão, recomendação, ato ou omissão, sempre que o considere: a) contrário à lei; b) pouco razoável, injusto ou opressivo, ou indevidamente discricionário, ou em desacordo com a lei; c) baseado em erro legal ou de fato; d) resultado de equívoco; e) decorrente do exercício da faculdade discricionária para fim indevido, por razões inexplicáveis, levando em consideração fatos irrelevantes, ou sem dar as razões da decisão.

Outrossim, o Ombudsman britânico foi implantado em 1967: é o Comissário Parlamentar (ou Comissionado Parlamentar Parliamentary Commissioner), designado pelo Poder Executivo, após longas negociações com o Parlamento. Suas funções podem ser interrompidas a qualquer momento, se perder a confiança do Parlamento. O Ombudsman inglês pode agir apenas se um pedido de investigação for formulado por parlamentares. É competente apenas 
em casos de maladministration (má-fé, negligência, inépcia, obstinação no erro, arbitrariedade ou similares). O Ombudsman britânico poderá investigar casos de maladministration provenientes de atividades meramente executivas do governo, mas deverá abster-se no tocante a atos de governo. O.Ombudsman britânico dispõe de poderes idênticos aos dos Tribunais.

Quanto ao Ombudsman canadense, verifica-se que, no plano federal do Canadá, existem dois Ombudsman: a) Comissário Oficial das Linguagens (Commissioner Official Languages), criado em 1969; b) Investigador Correcional (Correctional Investigator), criado em 1973. O primeiro protege o sistema bilingüe; o segundo fiscaliza a administração penitenciária. No Canadá, a implantação do Ombudsman começou a nível provincial, tendo posteriormente atingido a área federal. As províncias canadenses de língua inglesa criaram Ombudsman de 1967 a 1977. Em 1968, a Província de Quebec aprovou a criação de um Ombudsman, o "Protetor do Cidadão". O Ombudsman canadense é designado pelo Lieutenant Governor, mediante prévia proposição da Assembléia Provincial, para mandato de cinco ou seis anos, revogável e renovável. No Canadá anglófono, o Ombudsman é competente para investigar qualquer decisão ou recomendação formulada ou qualquer ato ou omissão de ato, relativo à Administração Pública. No Canadá francófono (Quebec), o âmbito de competência do Ombudsman é extremamente amplo, envolvendo funções administrativas, com exclusão de atos de governo. Os instrumentos principais da ação do Ombudsman são o Relatório Anual ao Parlamento e a publicidade de seus atos.

Nos Estados Unidos da América, a proposta de criação de um Ombudsman federal não foi aprovada, mas foram criados Ombudsman em alguns Estados daquela Federação, como Havaí (1967), Nebraska (1969), Iowa (1972), New Jersey (1974) e Alasca (1975), bem como em algumas cidades (como Filadélfia e Seattle). Os Ombudsman dos Estados Unidos da América dispõem de competência para apreciar: a) ato contrário à lei; b) ato irracional, injusto, opressivo ou desnecessariamente discricionário, mesmo estando de acordo com a lei; c) ato baseado em erro de fato; d) ato baseado em fundamentos impróprios ou inconseqüentes; e) ato sem adequada motivação; f) motivo que provoque inconformismo do indivíduo atingido. Os Ombudsman, nos EUA, podem agir de ofício ou mediante queixa de qualquer cidadão, de forma 
livre e direta. Têm as mesmas prerrogativas dos Juízes e suas decisões não são passíveis de revisão judicial. Se o Ombudsman considerar que um funcionário é culpado e este não revir sua posição, o Ombudsman poderá incriminá-lo perante os Tribunais.

Em relação à França, o Ombudsman francês denomina-se Médiateur: foi criado por Lei de 3 de janeiro de 1973. A designação de Mediador é feita pelo Conselho de Ministros, mediante decreto. Seu mandato é de seis anos, não podendo ser destituído pelo Conselho. $\mathrm{O}$ Mediador tem competência em relação a toda a Administração francesa, inclusive a local, com abrangência dos serviços administrativos, comerciais e industriais. A competência do Mediador restringe-se a direito individual afetado. No tocante à Justiça, o Médiateur pode intervir somente: a) se existir urgência na decisão, em virtude de condições sociais, saúde ou idade do reclamante; b) quando a Administração engendrar manobras protelatórias. $O$ Mediador somente recebe queixas remetidas pelos Deputados. Não pode agir de ofício. Os instrumentos de ação do Médiateur francês são os seguintes: a) poder de crítica em relação ao ato praticado; b) poder de aconselhamento ao funcionário faltoso; c) poder de repreensão disciplinar ou penal, podendo propor ação penal contra o funcionário faltoso; d) poder de publicidade; e) poder de sugestão.

Em Portugal, foi em 1974 implantado o Provedor de Justiça, o Ombudsman português. Foi definido como "órgão público independente", eleito pela Assembléia da República, com garantias de independência, inamovibilidade e imunidade. Pode atuar de ofício ou mediante recebimento de queixas contra qualquer funcionário administrativo, visando a correção de erros, atos administrativos ilegais e a melhoria dos serviços. Segundo seu atual titular, o Provedor de Justiça de Portugal funciona como um "contrapoder do Estado", figurando em terceiro lugar na hierarquia portuguesa, após o Presidente da República e o Primeiro Ministro.

Na Espanha, existe o Defensor do Povo (Alto Comissariado das Cortes Gerais), designado pelo Parlamento. O mandato é de quatro anos, podendo ser destituído por manifestação de três quintos de cada Câmara. Incumbe ao Defensor do Povo controlar toda a Administração Pública e "entes públicos personificados", inclusive o militar. Com informalidade processual, o Defensor do Povo age de ofício ou mediante provocação. 
Em Israel, começou a funcionar o Censor-Geral em 22 de setembro de 1971. A designação do Censor-Geral é efetuada pelo Presidente do Estado de Israel, mediante aprovação do nome escolhido pelo Knesset, o Parlamento israelense. Goza de independência em relação ao Governo, prestando contas somente ao Knesset. O Censor-Geral pode receber queixas de indivíduos, sem distinção de nacionalidade ou residência, contra ato de qualquer funcionário da Administração israelense e pode fiscalizar atos da Magistratura.

Como fecho deste estudo, salienta-se como imprescindível analisarse o tema Ombudsman em relação ao Brasil.

No início da década de oitenta, foi apresentado ao Congresso Nacional um projeto de lei, de autoria do Senador Marco Maciel, para instituição do "Ouvidor Geral", mas tal projeto não foi aprovado (aliás, a denominação "Ouvidor Geral" corresponde à vetusta instituição do OuvidorGeral atinente à época do Brasil-Colônia). Durante a Assembléia Nacional Constituinte (1987/1988), tramitou proposição para criação do Defensor do Povo, no âmbito da Constituição da República Federativa do Brasil, de 05 de outubro de 1988: porém, lobbies poderosos impediram a criação do Defensor do Povo, sobretudo lobbies provenientes do Tribunal de Contas da União e do Ministério Público (Federal e Estaduais).

É mister salientar-se, todavia, que o Decreto federal $\mathrm{n}^{\mathrm{Q}}$ 93.714, de 15 de dezembro de 1986, instituiu a Comissão de Defesa dos Direitos do Cidadão CÓDICI, materialmente assemelhada a um Ombudsman.

Com efeito, estipula o art. $1^{o}$ do Decreto federal $\mathbf{n}^{Q} 93.714 / 86$ que "as atividades dos órgãos da Administração Federal estão sujeitos à fiscalização permanente de qualquer pessoa, que poderá exercer o direito de representação e de petição ao Poder Executivo, a qualquer tempo e em quaisquer circunstâncias, na defesa de direito ou contra erros, omissões ou abusos de autoridades administrativas".

Ademais, assenta o Decreto federal oำ 93.714/86 o seguinte:

"art. $3^{\circ}$ A reclamação, para os fins previstos neste Decreto, será assinada pelo reclamante e instruída, quando possivel, com os documentos que a comprovam, 
ou com indicação de outras provas, inclusive a testemunhal";

"art. 50 - Incumbe, ainda, à CÓDICI:

I comunicar às autoridades administrativas competentes a conduta de agentes da Administração Federal, que possa caracterizar exercício ilícito ou abusivo da função administrativa;

II recomendar, à Consultoria-Geral da República, a adoção de medidas, providências ou ações, com o objetivo de restabelecer, na prática administrativa, a estrita observáncia dos princípios da legalidade, finalidade e moralidade administrativa;

III - adotar providências, junto aos órgãos $e$ autoridades competentes, destinadas a prevenir, reprimir ou fazer cessar a incorreção de comportamentos administrativos considerados ilegais, abusivos ou arbitrários;

$I V$ - sugerir aos óngāos componentes da Advocacia Consultiva da União, ou ao órgão competente do Ministério Público, a adoção de medidas administrativas ou judiciais, que visem a resguardar ou preservar a intangibilidade do interesse público";

"art. $8^{o}$ - A CÓDICI elaborará, anualmente, relatório circunstanciado das atividades por ela desenvolvidas, com fundamento neste Decreto.

Parágrafo único. $O$ relatório, de que trata este artigo, após aprovação do Presidente da República, será remetido à Câmara dos Deputados, ao Senado Federal e ao Tribunal de Contas da União, para conhecimento, bem assim a outros óngãos a que essa medida seja determinada". 
Sob o enfoque jurídico, o Decreto federal $\mathrm{n}^{\mathfrak{Q}}$ 93.714/86 é passível de severa crítica, em vista de sua manifesta inadequação.

$A b$ initio, evidencia-se que órgão administrativo de tal natureza deveria, no mínimo, ser criado por lei federal ordinária e ulteriormente instituído e regulamentado por decreto, embora o ideal consista em que seja previsto por norma constitucional programática, para posteriormente ser criado por lei. Sob o aspecto formal, é absurda a criação de órgão com tais competências por mero decreto federal, como sucedeu à CóDICI, embora o Decreto federal $\mathrm{n}^{2}$ 93.714/86 haja sido emitido, na época, com fundamento na então vigente Constituição da República.

Sob o aspecto material, a CÓDICI nunca dispôs da imprescindível autonomia funcional em relação aos três Poderes, mormente no tocante ao Poder Executivo. Basta relembrar-se e realçar-se que a CóDICI consiste de simples órgão administrativo do próprio Poder Executivo da União instituŕda junto à Presidência da República como "órgão colegiado integrante do Gabinete Pessoal do Presidente" (sic). Como órgão colegiado, a CóDICI foi constituída por representantes do Gabinete Militar, da Consultoria-Geral da República, da Secretaria de Administração Pública da Presidência da República, do Gabinete Civil e do Ministério Público Federal, sem prejuízo das respectivas funções, "os quais serão designados pelo Presidente da República, sob a presidência de quem este indicar" (sic)!

Percebe-se que, afinal, a CóDICI nunca passou, desde sua criação, de banalíssimo órgão administrativo de controle interno, mero arremedo de Ombudsman, malengendrado e pessimamente estruturado, sem condiçóes jurídicas e/ou políticas para desenvolver atividades como as de um verdadeiro Ombudsman, com independência e autonomia em relação aos três Poderes. Nota-se, ainda, que um verdadeiro Ombudsman é, quase sempre, um mandatário do Parlamento ou no mínimo aprovado pelo Parlamento, jamais um órgão monocrático ou colegiado do Poder Executivo, a este subordinado e sem mandato próprio, como sucedeu à CóDICI. A CÓDICI consiste, enfim, de uma experiência virtualmente inútil, com resultado pífio.

Em tese, sustentamos que, no Brasil atual, deste ano de 1991, a premente necessidade de um verdadeiro Ombudsman, apto a controlar severamente toda a Admipistração Pública, atinente aos três Poderes, poderia 
ser suprida mediante a dilatação, especialização e consolidação definitivas das competências constitucionais e legais dos Tribunais de Contas.

Com efeito, dispõe o artigo 70 da Constituição Brasileira, de 1988, que "a fiscalização contábil, financeira, orçamentária, operacional e patrimonial da Uniāo e das entidades da administração direta e indireta, quanto à legalidade, legitimidade, economicidade, aplicação das subvençōes e renúncia de receitas, será exercida pelo Congresso Nacional, mediante controle externo, e pelo sistema de controle interno de cada Poder" (caput).

E assenta o artigo 71 da Constituição da República, de 1988, que

"o controle externo, a cargo do Congresso Nacional, será exercido com o auxílio do Tribunal de Contas da União, ao qual compete:

IV - realizar, por iniciativa própria, da Câmara dos Deputados, do Senado Federal, de Comissão técnica ou de inquérito, inspeções e auditoria de natureza contábil, financeira, orçamentária, operacional e patrimonial, nas unidades administrativas dos Poderes Legislativo, Executivo e Judiciário, e demais entidades referidas no inciso II;

$L X$ - assinar prazo para que o órgão ou entidade adote as providências necessárias ao exato cumprimento da lei, se verificada ilegalidade;

$X I$ - representar ao Poder competente sobre irregularidades ou abusos apurados;

$\S 49$ - O Tribunal encaminhará ao Congresso Nacional, trimestral e anualmente, relatório de suas atividades"

Entrementes, proclama o artigo $74\left(\S 2^{2}\right)$ da Constituição da República, de 1988, o seguinte: "Qualquer cidadão, partido político, associação ou 
sindicato é parte legítima para, na forma da lei, denunciar irregularidades ou ilegalidades perante o Tribunal de Contas da União".

Em vista dos dispositivos constitucionais supratranscritos, em vigor no Brasil atual, verifica-se que os Tribunais de Contas brasileiros já dispõem de competências para desempenhar funções de verdadeiros Ombudsman, a depender apenas de cabal regulação por legislação ordinária. No Brasil, a rigor, não há necessidade de criação de Ombudsman, em face das atuais competências constitucionais dos Tribunais de Contas !

Seria necessário, apenas, que legislação ordinária criasse, no âmbito dos Tribunais de Contas do Brasil, seções especializadas ou câmaras específicas, encarregadas de controlar a observância da legalidade, legitimidade e eficiência, no âmbito da Administração Pública dos três Poderes, podendo representar ao Poder competente sobre irregularidades ou abusos apurados. Assim, restariam respeitadas as competências constitucionais e legais dos três Poderes e seus respectivos órgãos, ressalvada a possibilidade de contrasteamento indicativo dos Tribunais de Contas, lato sensu, como órgão administrativo autônomo do Poder Legislativo.

A criação de tais câmaras especializadas, nos Tribunais de Contas do Brasil, poderia corresponder ao magistério do Professor Dr. Caio Tácito: "o controle a ser exercido sobre a Administração Pública atenderá a esse duplo endereço de sua atividade: de um lado, o controle da legalidade, visando à preservação dos direitos dos administrados e do patrimônio público; de outra parte, $o$ controle de eficiência, que tem em mira o aperfeiçoamento das instituições administrativas, cuidando de sua melhor produtividade." (O Controle da Administração e a Nova Constituição do Brasil, $R D A \mathrm{n}^{\mathrm{Q}} 90$, outubro/dezembro de 1967, p. 24).

O Brasil já tem seu Ombudsman, embora com outra denominação: trata-se dos Tribunais de Contas brasileiros, que dispóem das mais vastas e abrangentes competências constitucionais, em termos de Direito Constitucional e Direito Administrativo Comparado, se cotejadas tais competências com as dos Tribunais de Contas de todos os Estados soberanos do Planeta Terra! 